\title{
Evaluation of Morphological Changes in the River Bharathapuzha Using DEM Images
}

\author{
Ardra Wilson $^{1 *}$ and B. Vishnu ${ }^{2}$ \\ ${ }^{1}$ Department of Soil and Water Conservation Engineering, KCAET, Tavanur, Malappuram, \\ Kerala - 679573, India \\ ${ }^{2}$ Regional Agricultural Research Station, Kerala Agricultural University, Kavanattinkara, \\ Kumarakom, Kerala - 686563, India \\ *Corresponding author
}

\section{A B S T R A C T}

\section{Keywords}

River morphology, cross section, DEM, ArcGIS, Elevation profile add-in

Article Info

Received: 02 November 2021 Accepted: 30 November 2021 Available Online: 10 December 2021
Rivers have been a subject of study by engineers and scientists who have been fascinated by their self-formed geometric shapes and their responses to changes in nature and human interference. Among various types of human interventions, indiscriminate extraction of sand and gravel is the most disastrous one, as it threatens the very existence of the riverine ecosystem. Bharatapuzha is a great victim of illegal sand mining. The mining activity is particularly very high in the stretch between Pattambi and Kuttippuram of Bharathapuzha river. The study was undertaken to assess the morphological changes utilising DEM imageries. The analysis and assessment of satellite imageries were carried out using the ArcGIS 10.3 software. The Elevation Profile add-in toolbar was utilised to create profile graphs by taking sections across the river course in ArcGIS and the morphological changes of the river were calculated by comparing the cross-section profiles for the time period 2000 to 2014. Profile graphs revealed an average change in river bed depth of $0.25 \mathrm{~m}$ and an average change of cross-sectional area of about 134.66 $\mathrm{m}^{2}$. The main cross-sectional changes in the river reach of Kuttippuram to Pattambi were channel deepening and channel widening.

\section{Introduction}

Rivers play a pivotal role in creating the world in which we live. They are the most prolific land surface sculptors. A variety of aweinspiring landforms are carved out under fluvial processes. The science of carving out landforms by river action is called river morphology (Garde, 2006). Elements of river channel are planform, cross-sectional shape and channel slope which constitute the morphological characters of rivers. Rivers continuously change their shape and reform their channels by eroding the channel 
boundary and through reworking and deposition of sediments. Always an equilibrium is maintained between the energy of the flow and the resistance by the bed and banks. Human influences on channels causes drastic changes and leads to rapid destabilization of equilibrium conditions. Among those actions uncontrolled sand mining had degraded the river and its adjoining areas to an irreparable level. (Padmalal and Maya, 2014). The scenario is terrific in Kerala State, in the southwest coast of India. The biodiversity and cultural richness of Kerala is nurtured by a great system of forty-four rivers. During the period 20052006, about 30 million tonnes of sand had been mined from more than 2000 sand mining sites of Kerala rivers and it is revealed that the river bed lowered at a rate of 5 to $20 \mathrm{~cm}$ per year (Sreebha, 2008). Among the rivers in Kerala, Bharathapuzha is one of the rivers severely disturbed due to sand mining. Stream's physical characteristics, such as channel geometry, bed elevation, composition and stability, in-stream roughness of the bed etc. had been directly affected by mining (Padmalal and Maya, 2014). Fluvial geomorphological surveys are highly popular during the last decade to support sustainable river management.

Field-based approaches limits the widespread application due to the difficulty in data collection (Napieralski et al., 2013).The objectivity and efficiency of river morphological investigations had greatly increased by the integration of remote sensing and GIS (Gilvear and Bryant, 2016). As, illegal sand mining is a common phenomenon in Bharathapuzha river, which is threatening the existence of the river itself and it is noted that high rate of mining is carried out in the Kuttippuram to Pattambi reach of Bharathapuzha. The present study was undertaken to evaluate the effect of sand mining on the morphology of the severely affected reach of Bharathapuzha River between Pattambi and Kuttippuram using remote sensing and GIS.

\section{Materials and Methods}

\section{Study area}

The Bharathapuzha ("River of Bhārata") is also known as the River Nila, Perar or Ponnanipuzha. It is the second longest river in Kerala with a total length of $209 \mathrm{~km}$ and it lies in the central part of Kerala state, India. The river is considered to be one of the westflowing 'medium' rivers of the country and lies approximately between $10^{\circ} 26^{\prime}$ and $11^{\circ}$ $13^{\prime}$ north latitudes and $75^{\circ} 53^{\prime}$ and $77^{\circ} 13^{\prime}$ east longitudes. Bharathapuzha originates at Kovittola Betta of Kundra reserve forest in the Western Ghats, located in Tamil Nadu, at an elevation of $2336 \mathrm{~m}$ above MSL, and flows westward to join the Arabian Sea at Ponnani (10 47' 13" N, 75 54' 40" E) Kerala, India (CWRDM, 1991, 2004).

The river valley is considered as the cradle of civilisation in Kerala and Nila has groomed the culture and life of south Malabar part of Kerala. The river is the life line water resource for almost one-eighth of Kerala's population residing in four administrative divisions, namely Malappuram, Thrissur and Palakkad districts of Kerala and partly Coimbatore, and Thiruppur districts of Tamil Nadu. Now it's a dead river with huge dry stretches. Noticeably, among the grave causes for the degradation of the river, sand mining is reported to be the dominant one. The mining activity is particularly bad in the stretch between Pattambi and Kuttippuram, as the steepness decreases in this reach. The river reach lying in between the towns Kuttippuram $\left(10^{\circ} 50^{\prime} 38^{\prime \prime} \mathrm{N}, 7^{\circ} 01^{\prime} 58^{\prime \prime} \mathrm{E}\right)$ in Malappuram district and Pattambi $\left(10^{\circ} 45^{\prime} 21.72^{\prime \prime} \mathrm{N}, 76^{\circ}\right.$ $\left.34^{\prime} 23.18^{\prime \prime} \mathrm{E}\right)$ in Palakkad district had been selected as the study area. 
DEM imageries were used to evaluate the effect of sand mining on the morphology of the Bharathapuzha river and its adjoining banks in the severely affected reach between Kuttippuram and Pattambi by analysing the cross-sectional details. CARTOSAT-1 DEM and SRTM DEM of the study area for the time periods 2014 and 2000 acquired from Earth Explorer and Bhuvan respectively were used to analyse the cross-sectional details. All imageries are of $30 \mathrm{~m}$ resolution. The imageries were processed and assessed using ArcGIS 10.3 software.

The Elevation Profile add-in toolbar was used to find out the morphological changes in the river channel by developing the cross-section profiles of various sections. The Elevation Profile add-in toolbar (Figure 1) allows to easily create profile graphs by simply drawing a line on the display in ArcGIS Desktop. It also allows to select existing line features and create profiles for them. By using this service, it is easy to create a profile graph on any elevation raster that is added to ArcMap.18 number of line features were drawn representing 18 cross sections (Figure 2) and the profile graphs were generated using the Elevation Profile add-in. The cross sections were named from $\mathrm{A}$ to $\mathrm{R}$ with the section $\mathrm{A}$ representing the area closer to Kuttipuram and $\mathrm{R}$ to Pattambi. Profile graphs were created from all the DEM imageries: CARTOSAT DEM, and SRTM. Results obtained by applying the Elevation Profile tool were compared to know the changes occurred to the channel cross sectional area between different time periods.

\section{Results and Discussion}

\section{Assessment of morphological changes}

The impacts of sand mining on river channel and its adjoining river banks were assessed by analysing the changes in the 18 -cross sections drawn across the river channel. River morphological changes indicates the change in shape and direction of river channel over time. Morphological changes of the river channel were analysed using the DEM imageries during 2000-2014. Profile graphs obtained from the elevation add-in depicted the average change in depth of the cross section and also the change in cross sectional area of each cross-sectional lines taken for the observation. The observations are listed in the Table 1.

The river reach from Kuttipuram to Pattambi according to the study revealed an average change in river bed depth of $0.25 \mathrm{~m}$ during the time period 2000-2014. The cross section of the entire reach experienced an average change of cross-sectional area of about 134.66 $\mathrm{m}^{2}$.The range of average change in bed depth was 1.03 to $0.05 \mathrm{~m}$. Some sections such as $\mathrm{H}$, J M, O, P and $\mathrm{Q}$ had no any significant changes in the depth of channel bed as well cross-sectional area. It clearly indicated that these cross-sectional areas were safe from the illegal practices of sand mining. The highest change in the average depth and cross sectional area was observed at section $\mathrm{A}$ as $1.03 \mathrm{~m}$ and $968.98 \mathrm{~m}^{2}$ respectively.

Cross sectional analysis in the 18 sections showed that most of the sections had undergone changes during the considered time period from 2000-2014. It was clear that drastic changes in the section was seen along the reach closer to Kuttippuram, i.e., the sections from A to G. No significant changes were visible in the other sections. Downstream regions were the areas of severe sand mining which had caused the drastic changes in the bed elevation of the river in the selected sections. The changes in area were caused mainly by lateral erosion which had caused the widening of channel. Mostly the downstream sections had observed channel widening. Upstream sections had not experienced any channel widening. 
Table.1 Observations of profile graphs of river cross section

\begin{tabular}{|c|c|c|}
\hline Section & Change in depth $(\mathbf{m})$ & Change in cross sectional area $\left.\mathbf{~}^{\mathbf{2}}\right)$ \\
\hline $\mathbf{A}$ & 1.03 & 968.98 \\
\hline $\mathbf{B}$ & 0.95 & 538.95 \\
\hline $\mathbf{C}$ & 0.30 & 136.52 \\
\hline $\mathbf{D}$ & 0.24 & 115.73 \\
\hline $\mathbf{E}$ & 0.05 & 30.66 \\
\hline $\mathbf{F}$ & 0.47 & 178.94 \\
\hline $\mathbf{G}$ & 0.07 & 27.02 \\
\hline $\mathbf{H}$ & 0.00 & 0.00 \\
\hline $\mathbf{I}$ & 0.55 & 140.93 \\
\hline $\mathbf{J}$ & 0.00 & 0.00 \\
\hline $\mathbf{K}$ & 0.43 & 150.82 \\
\hline $\mathbf{L}$ & 0.05 & 22.05 \\
\hline $\mathbf{M}$ & 0.00 & 0.00 \\
\hline $\mathbf{N}$ & 0.44 & 113.24 \\
\hline $\mathbf{O}$ & 0.00 & 0.00 \\
\hline $\mathbf{P}$ & 0.00 & 0.00 \\
\hline $\mathbf{Q}$ & 0.00 & 0.00 \\
\hline $\mathbf{R}$ & 0.00 & 0.00 \\
\hline Average & $\mathbf{0 . 2 5}$ & $\mathbf{1 3 4 . 6 6}$ \\
\hline & & \\
\hline
\end{tabular}

Fig.1 Elevation profile add-in toolbar

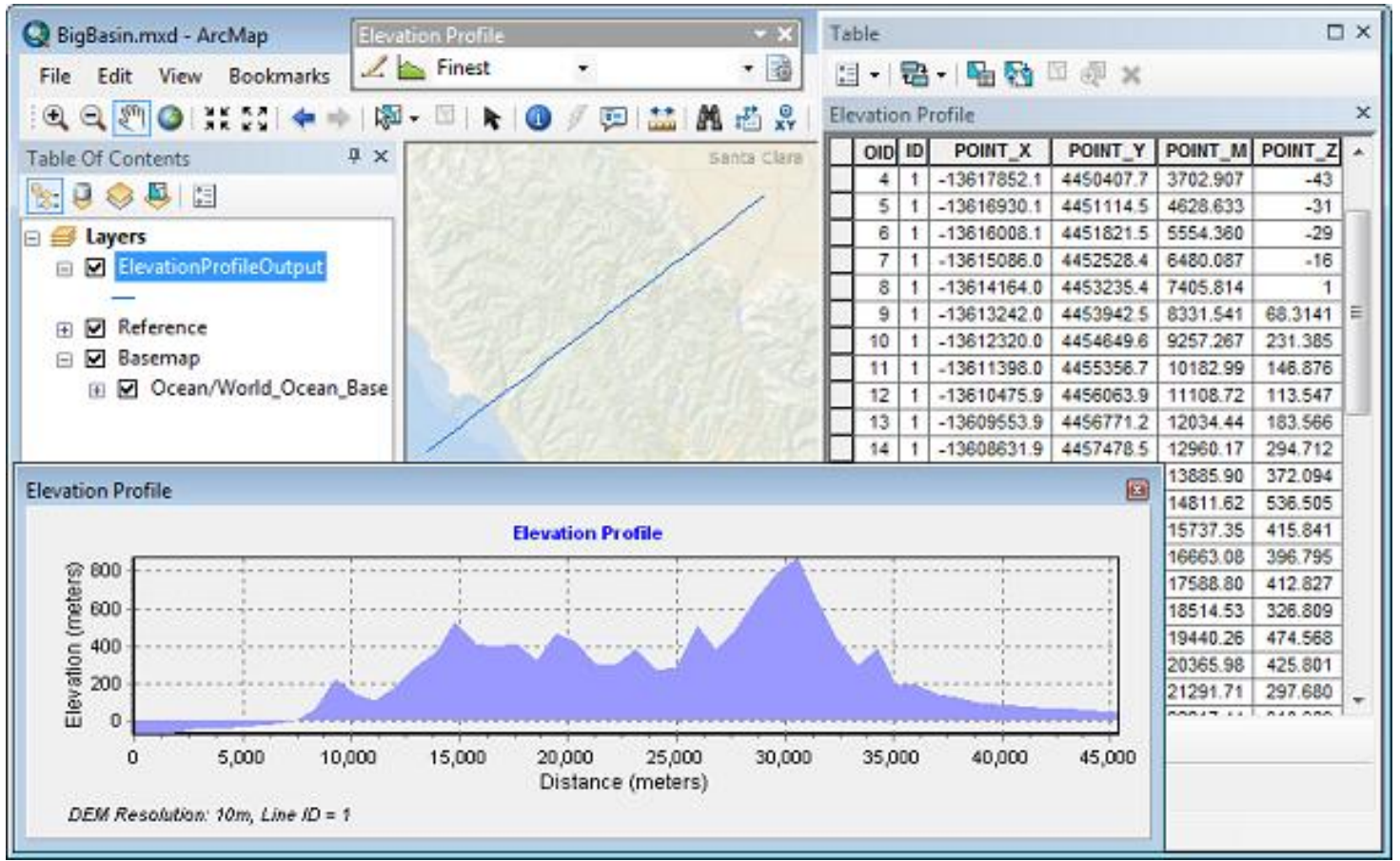


Fig.2 Line feature to create profile graph of channel cross section

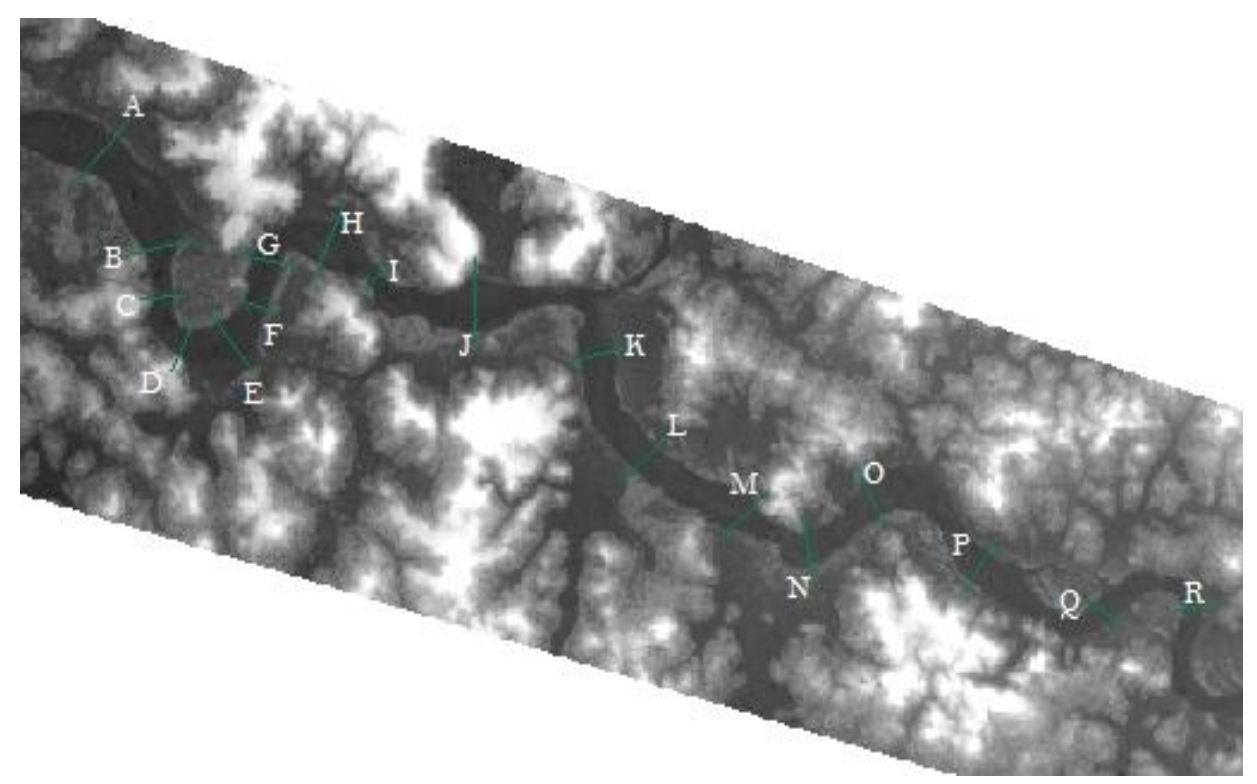

Aravindan (2002) had reported that the endless mining had deepened the river bed. Santhosh and Sreeja (2012), Abubakar and Bashir (2013) had reported extreme sand mining as the reason of channel scouring and bank erosion mainly in downstream which had deepened the river bed and widened the river channel. The main cross-sectional changes in the river reach of Kuttippuram to Pattambi were the channel deepening and channel widening and these changes were highly visible in the sections closer to Kuttippuram of the reach.

\section{References}

Abubakar and Bashir. 2013. Changes in channel morphology and its socio economic impact on the riverine communities in Yola area. Int. J. Environ. Ecol. Family and Urban Stud. 3(4): 23-30

Aher, S. P., Bairagi, S. I., Deshmukh, P. P., and Gaikwad, R. D. 2012. River Change Detection and Bank Erosion Identification using Topographical and Remote Sensing Data. Int. J. Appl. Inf. Syst.2(3): 1-7.
Alam, J. B., Uddin, M., Uddin, A. J., Cacovean, H., Habibur, R. M., Banik, B. K. and Yesmin, N. 2007. Study of morphological change of river old Brahmaputra and its social impacts by Remote Sensing. GeographiaTechnica. 2:1-11.

Aravindan. 2002. Sand mining defaces rivers. The Hindu, 27 Mar. 2002, p.4.

Buckhingam, S. E. and Whitney, J. W. 2007. Gis methodology for quantifying channel change in Las Vegas, Nevada. J. Am. Water Res. Assoc. 43(4): 88889

CWRDM, 1991. Water Resources Development of Bharathapuzha Basin, a Status Report. Centre for Water Resources Development and Management. Kozhikode, Kerala.

Darwish, K., Smith, S. E., Torab, M., Monsef, H., Hussein, O. 2016. Geomorphological Changes along the Nile Delta Coastline between 1945 and 2015 Detected Using Satellite Remote Sensing and GIS. J. Coastal Res. 15(9): 1-9.

Garde, R. J. 2006. River Morphology. New Age International (P) Limited 
Publishers, New Delhi, 502p.

Gilvear, D. and Bryant, R. 2016. Tools in Fluvial Geomorphology (2nd Ed.). John Wiley and Sons Limited Publishers, UK, 31p.

Gogoi, C. and Goswami D. 2014. A study on channel migration of the Subansiri river in Assam using remote sensing and GIS technology. Curr. Sci. 106(8): 1113-1120

Napieralski, J., Barr, I., Kamp, U. and Kervyn, M. 2013. Remote sensing and GIS science in geomorphological mapping. Treatise on geomorphology (3rd Ed). Academic Press Publishers, San Diego, pp.187-329.

Padmalal, D. and Maya, K. 2014. Sand mining - Environmental impacts and selected case studies. Springer, New York, $177 \mathrm{p}$.

Santhosh, K. A. and Sreeja, S. K. 2012. Indiscriminate river sand mining: a manmade disaster in Kerala, India. Bionano Frontier. 46-50.

Sreebha, S. 2008. Environmental impact of sand mining: A case study in the river catchments of Vembanad lake, Southwest India. $\mathrm{PhD}$ thesis, Centre for Earth Science Studies, Thiruvananthapuram, 353p.

\section{How to cite this article:}

Ardra Wilson and Vishnu, B. 2021. Evaluation of Morphological Changes in the River Bharathapuzha Using DEM Images. Int.J.Curr.Microbiol.App.Sci. 10(12): 304-309. doi: https://doi.org/10.20546/ijcmas.2021.1012.035 